\title{
Influence of the Semi-dwarf Growth Type on Nitrogen Use Efficiency in Winter Oilseed Rape
}

\author{
Sebastian Miersch, Andreas Gertz, Frank Breuer, Antje Schierholt, and Heiko C. Becker^
}

\begin{abstract}
A higher nitrogen $(\mathrm{N})$ use efficiency is an important breeding goal in crops such as oilseed rape (Brassica napus L.) that are considered less $\mathrm{N}$ efficient compared with crops like wheat (Triticum aestivum L.) or barley (Hordeum vulgare L.). Changes in the plant ideotype, such as reduced plant height of semi-dwarf hybrids, are said to result in an increased harvest index and $\mathrm{N}$ harvest index. This could lead to a higher $\mathrm{N}$ efficiency, especially when $\mathrm{N}$ availability is restricted. A double haploid population was developed that was segregating for the bzh dwarf locus, with 54 dwarf and 54 normal-type lines. By crossing with a normal-type tester, 108 testcrosses were produced with 54 hybrids each of semi-dwarf and normal types. They were evaluated for seed yield, straw yield, and $\mathrm{N}$ content under zero and high $\mathrm{N}$ fertilization in six and four trials, respectively, in the years 2010 to 2013. Quantitative trait loci were estimated for N-related traits across environments. Semidwarf hybrids showed a significantly higher $\mathrm{N}$ harvest index, $\mathrm{N}$ uptake efficiency, $\mathrm{N}$ utilization efficiency, and $\mathrm{N}$ use efficiency compared with normal-type hybrids at $\mathrm{N}$ deficiency. The relative contribution of $\mathrm{N}$ uptake efficiency to the total genetic variation in $\mathrm{N}$ use efficiency was higher in semi-dwarf genotypes than in normaltype hybrids at both $\mathrm{N}$ levels. Quantitative trait loci of five and two $\mathrm{N}$-related traits under zero and high $\mathrm{N}$ fertilization, respectively, cosegregated with the bzh-locus on linkage group A06, indicating that the semi-dwarf growth type has a high influence on $\mathrm{N}$ efficiency. We conclude that semi-dwarf hybrids are better adapted to $\mathrm{N}$ deficiency.
\end{abstract}

S. Miersch, A. Schierholt, H.C. Becker, Georg-August Univ. Göttingen, Dep. of Crop Sciences, Von Siebold Strasse 8, 37075 Göttingen, Germany; A. Gertz, F. Breuer, KWS SAAT SE, Grimsehlstrasse 31, 37555 Einbeck, Germany. Received 20 Jan 2016. Accepted 2 July 2016. *Corresponding author (hbecker1@gwdg.de). Assigned to Associate Editor Jessica Torrion.

Abbreviations: DH, double haploid; Ei, Einbeck; Go, Göttingen; HI, harvest index; NHI, nitrogen harvest index; Ns, total nitrogen supply; QTL, quantitative trait loci; Var.cp., components of variance.

C ROps with an improved $\mathrm{N}$ efficiency need less $\mathrm{N}$ fertilization per unit seed yield, which benefits the environment by preventing $\mathrm{N}$ pollution and increases the economic gain of the crop producer. Two recent European Union regulations focus thereon: directive 2009/28/EC on the promotion of the use of energy from renewable sources (European Parliament and the Council of the European Union, 2009), which limits greenhouse gas emissions in the production of energy crops, including the energy-intensive production of mineral $\mathrm{N}$ fertilizer, and the nitrates directive (1991/676/EEC), which restricts the $\mathrm{N}$ balance surplus of a crop rotation (Council of the European Communities, 1991). In Germany, it has been regulated since 2009 that the average $\mathrm{N}$ balance surplus of a 3 -yr field rotation period should be below $60 \mathrm{~kg} \mathrm{~N} \mathrm{ha}^{-1}$ (Deutsche Düngeverordnung, 2006). Within the group of major crops, oilseed rape is less $\mathrm{N}$ efficient than sugar beet (Beta vulgaris L.), wheat, and barley (Sylvester-Bradley and Kindred, 2009), and the $\mathrm{N}$ balance surplus of winter oilseed rape is high compared with the latter. Next to changes in current field management practices, such as skipping the autumn $\mathrm{N}$ fertilizer application in oilseed rape (Henke et al., 2009), the breeding of $\mathrm{N}$ efficient rapeseed can contribute to a better $\mathrm{N}$ balance.

Published in Crop Sci. 56:2952-2961 (2016).

doi: 10.2135/cropsci2016.01.0044

(C) Crop Science Society of America | 5585 Guilford Rd., Madison, WI 53711 USA All rights reserved. This is an open access article distributed under the CC BY-NC-ND license (http://creativecommons.org/licenses/by-nc-nd/4.0/). 
Definitions of $\mathrm{N}$ use efficiency and its related traits are plentiful (reviewed in Han et al., 2015), as $\mathrm{N}$ use efficiency involves different physiological steps, including uptake, assimilation, translocation, and remobilization (Good et al., 2004; Masclaux-Daubresse et al., 2010). Nitrogen use efficiency, in the broadest sense, indicates how efficiently a plant is able to capture and utilize $\mathrm{N}$ to produce biomass or grain yield (Good et al., 2004). From a plant breeding point of view, Moll et al. (1982) invented one of the most reasonable descriptions for the analysis of genetic variation in $\mathrm{N}$ efficiency in maize (Zea mays L.), defining $\mathrm{N}$ use efficiency as grain production per unit of $\mathrm{N}$ available in the soil. Nitrogen use efficiency can accordingly be split into two components: $\mathrm{N}$ uptake efficiency and $\mathrm{N}$ utilization efficiency. Nitrogen uptake efficiency is described as the amount of $\mathrm{N}$ acquired by a genotype as a proportion of the $\mathrm{N}$ available in the soil. Nitrogen utilization efficiency is given in units of grain yield per unit of $\mathrm{N}$ acquired. By estimating the relative contribution of uptake and utilization efficiency to the total genetic variation in $\mathrm{N}$ use efficiency, Moll et al. (1982) enabled conclusions related to the genetic variation within the tested material. This approach is very useful in plant breeding and was therefore used in this study.

Variation in $\mathrm{N}$ efficiency within oilseed rape cultivars was observed in several studies. For example, Berry et al. (2010) and Schulte auf'm Erlay et al. (2011) described significant varietal differences in $\mathrm{N}$ uptake and utilization at low $\mathrm{N}$ supply and differences in $\mathrm{N}$ uptake at low and at high $\mathrm{N}$ supply, respectively, in multilocation field trials with line and hybrid cultivars. Kessel et al. (2012) analyzed a more genetically diverse set of genotypes, which included old cultivars and nonadapted resynthesized lines, in a multilocation trial in Northern Europe, where they detected significant genetic variation for $\mathrm{N}$ uptake and utilization efficiency. At low $\mathrm{N}$ conditions, $\mathrm{N}$ uptake proved to be more important for seed yield than $\mathrm{N}$ utilization, whereas with increasing $\mathrm{N}$ supply, $\mathrm{N}$ utilization became more important (Berry et al., 2010; Kessel et al., 2012). Significant genotype $\times \mathrm{N}$ level interactions indicated that genotypes selected for high yield at high $\mathrm{N}$ conditions might not be high yielding under low $\mathrm{N}$ conditions (Berry et al., 2010; Kessel et al., 2012). Nyikako et al. (2014) found significant genetic variation for $\mathrm{N}$ uptake efficiency and $\mathrm{N}$ utilization efficiency in a field test of unselected double haploid (DH) lines. They concluded from the positive correlations at low $\mathrm{N}$ supply between harvest index (HI) and $\mathrm{N}$ use efficiency $\left(r=0.45^{\star \star}\right)$, and $\mathrm{HI}$ and $\mathrm{N}$ utilization $\left(r=0.46^{\star \star}\right)$, that a shorter plant ideotype could be more $\mathrm{N}$ efficient at low $\mathrm{N}$ supply. In oilseed rape, several dwarf genes were described (Miersch et al., 2016), and the first cultivar carrying the additively controlled $b z h$ dwarf locus ('Lutin') was released to the French market in 1999 (Pinochet and Renard, 2012). The effects of plant height and
$\mathrm{HI}$ on $\mathrm{N}$ use efficiency were already in the focus of Sieling and Kage (2008), who compared three normal-type and one dwarf-type cultivars, and of Koeslin-Findeklee et al. (2014), who compared lines, hybrids, and dwarf types. Sieling and Kage (2008) found similar HI and nitrogen $\mathrm{HI}$ (NHI) for the four cultivars tested. Koeslin-Findeklee et al. (2014) did not find significant differences in NHI between the groups of lines, hybrids, and dwarf types at either $\mathrm{N}$ level. Dwarf types had a significantly higher HI compared with lines at high $\mathrm{N}$ supply, whereas there was no difference at low $\mathrm{N}$ supply.

In this study, we investigated $\mathrm{N}$ uptake, $\mathrm{N}$ utilization, and $\mathrm{N}$ use efficiency parameters in 108 hybrids derived from a $\mathrm{DH}$ population segregating into semi-dwarf types and normal types. The 108 hybrids had been evaluated for seed yield at high and low $\mathrm{N}$ supply in five and seven environments, respectively (Miersch et al., 2016), where semi-dwarf hybrids yielded significantly higher than normal types and had a significantly higher HI when $\mathrm{N}$ was scarce. In earlier studies on the effect of the semi-dwarf growth type (Sieling and Kage, 2008; Koeslin-Findeklee et al., 2014), the authors compared genetically different, unrelated cultivars that differed not only in growth type, but also in many other characteristics. In this experiment, we compare semi-dwarf and normal-type hybrids, which were derived from a segregating and unselected DH population with the same segregating genetic background.

The hypothesis of this study was that semi-dwarf winter oilseed rape hybrids are better adapted to low $\mathrm{N}$ environments than normal-type hybrids. We analyzed the effects of the $b z h$ dwarf gene on N-efficiency-related parameters and investigated by quantitative trait loci (QTL) analysis whether the dwarf gene is the cause for differences in $\mathrm{N}$ uptake, $\mathrm{N}$ utilization, and $\mathrm{N}$ use efficiency between semi-dwarf and normal-type hybrids.

\section{MATERIALS AND METHODS Plant Material and Field Trials}

Fifty-four semi-dwarf hybrids and 54 normal-type hybrids were derived from crosses of DH lines from population 'Alesi- $b z h \times$ H30' with a normal-type, highly homozygous and male-sterile winter oilseed rape tester (Miersch et al., 2016) with canola seed oil quality. The hybrids segregated into semi-dwarf $(b z h / B z h)$ and normal type $(B z h / B z h)$. 'Alesi-bzh' is a dwarf isogenic line derived from the German winter oilseed cultivar 'Alesi,' backcrossed (BC4) from the bzh dwarf mutant. Foisset et al. (1995) selected the $b z h$ dwarf mutant where the growth type is controlled additively by the $b z h$ gene, which was mapped onto the distal end of B. napus linkage group DY6 (Foisset et al., 1996). 'H30' is a normal-type, resynthesized rapeseed line, originating from a cross of $B$. rapa ssp. chinensis with $B$. napus ssp. napus var. pabularia (Girke et al., 2011).

All hybrids were tested during the 2010 to 2011, 2011 to 2012, and 2012 to 2013 seasons, at two locations in the central German mega-environment with two $\mathrm{N}$ levels (Table 
1). Location Einbeck (Ei) has brunic aerosol and Göttingen (Go) alluvial meadow soils. Season-location combinations are considered environments and are addressed throughout the manuscript by location abbreviation and harvest year, such as Ei2011 for Einbeck in the 2010 to 2011 season. In each trial, 108 hybrids (54 normal-type and 54 semi-dwarf) were grown in blocks with two replications. Within each block, growth types were interlaced by alternately growing one strip of semidwarfs and one strip of normal-types. The plot sizes were $18 \mathrm{~m}^{2}$ in Einbeck and $11.25 \mathrm{~m}^{2}$ in Göttingen, with plant densities of 50 and 90 plants $\mathrm{m}^{-2}$, respectively. Experiments were designed as split-split-plots, with $\mathrm{N}$ level as a main plot factor, growth type as a subplot factor, and genotype within growth type as a sub-subplot factor. Genotypes within growth types were sorted in a lattice design, with the exception of season 2010 to 2011, where a randomized block design was used. Weed, disease control, pest control, fertilization (with the exception of $\mathrm{N}$ ), and all agronomic treatments followed the recommendations for winter oilseed rape production in Germany.

The experiments were conducted with two levels of $\mathrm{N}$ fertilization: zero $\mathrm{N}$ and optimal $\mathrm{N}$ supply. At each location, the soil mineral $\mathrm{N}$ content $\left(\mathrm{N}_{\min }\right)$ was determined in the spring at the beginning of plant growth (Table 1). Soil samples were taken from 0 - to $90-\mathrm{cm}$ depth, and the $\mathrm{N}_{\min }$ was analyzed following the method of VDLUFA (1991). For zero $N$ trials, no $\mathrm{N}$ fertilizer was applied. For trials with optimal $\mathrm{N}$ supply, 177 $\mathrm{kg} \mathrm{N} \mathrm{ha}{ }^{-1}$ were applied. About one half of the $\mathrm{N}$ was applied as ammonium sulfate fertilizer plus calcium ammonium nitrate fertilizer in the spring at the beginning of plant growth $\mathrm{BBCH}$ 30; Lancashire et al., 1991). The other half was applied as calcium ammonium nitrate fertilizer at the beginning of shoot development (BBCH 32). The fertilization with sulfate is considered to have no effect, because plant analyses in a parallel experiment on the same field showed a normal sulfur status even in unfertilized plots. Beginning of flowering was defined as days from January 1 and was recorded at $\mathrm{BBCH} 61$, when $10 \%$ of the plants flowered. Plant height in $\mathrm{cm}$ was measured at grain maturity (BBCH 89).

For seed and straw yield, plots were harvested at maturity (BBCH 89) with a Hege 160 combine harvester (Hans-Ulrich Hege GmbH \& Co., Waldenburg-Hohebuch, Germany). Plants were cut right above soil level, and straw was collected and weighed in a tarp attached to the back of the harvester. A straw subsample including stems and pods was dried at $60^{\circ} \mathrm{C}$ for $48 \mathrm{~h}$ in a drying oven to determine straw dry matter content.

\section{Quality Analyses}

Nitrogen content in straw was determined by the Dumas-based combustion method using a CN Elemental Analyser, type vario EL (Elementar Analysensysteme GmbH, 63452 Hanau, Germany). For the $\mathrm{N}$ analysis, an oven-dried subsample of straw was milled to particle sizes of $0.2 \mathrm{~mm}$. Seed protein, seed $\mathrm{N}$, and moisture content were determined with a near infrared reflectance spectroscopy (NIRS) monochromator model 6500 (Foss NIRSystems, Silver Spring, MD) using calibrations (raps2011. eqa, raps2012.eqa, and raps2013.eqa) provided by VDLUFA Qualitätssicherung NIRS GmbH (Am Versuchsfeld 13, 34128 Kassel, Germany).

\section{Estimation of Nitrogen-Related Parameters}

Seed $\mathrm{N}$ yield $\left(\mathrm{kg} \mathrm{N} \mathrm{ha}^{-1}\right)$ was calculated on the basis of the seed dry matter yield and $N$ content in the seeds (\%). Straw $N$ yield ( $\mathrm{kg} \mathrm{N} \mathrm{ha}{ }^{-1}$ ) was calculated as the product of straw dry matter yield and $\mathrm{N}$ content in the straw. Nitrogen yield at maturity was estimated as the sum of $\mathrm{N}$ in straw and seeds. The NHI was estimated by dividing the seed $\mathrm{N}$ yield by the total $\mathrm{N}$ yield at maturity.

Nitrogen use efficiency is defined as seed production per unit of $\mathrm{N}$ available in the soil, and $\mathrm{N}$ uptake efficiency and $\mathrm{N}$ utilization efficiency were calculated according to Moll et al. (1982) using the following equations:

$$
\begin{aligned}
& \mathrm{N} \text { use efficiency }=\text { Seed yield } / N_{\mathrm{s}} \\
& \mathrm{N} \text { uptake efficiency }=N_{\mathrm{t}} / N_{\mathrm{s}} \\
& \mathrm{N} \text { utilization efficiency }=\text { Seed yield } / N_{\mathrm{t}}
\end{aligned}
$$

where $N_{\mathrm{s}}$ is the total $\mathrm{N}$ supply and $N_{\mathrm{t}}$ is the total $\mathrm{N}$ uptake (above ground) of a genotype at maturity. The $\mathrm{N}$ supply in the unfertilized treatment was defined in each replication by the highest amount of total $\mathrm{N}$ taken up by a genotype at maturity. The $N$ supply of the fertilized treatment was the sum of the mean $\mathrm{N}$ supply of unfertilized replications and the amount of $\mathrm{N}$ fertilizer. The $N_{\mathrm{s}}$ and $N_{\mathrm{t}}$ are expressed in the same units as the seed yield $\left(\mathrm{kg} \mathrm{ha}^{-1}\right)$.

The relative contributions of $\mathrm{N}$ uptake and utilization efficiency to the total genetic variance in $\mathrm{N}$ use efficiency were

\begin{tabular}{|c|c|c|c|c|c|c|c|c|}
\hline \multirow[b]{2}{*}{ Location } & \multirow[b]{2}{*}{ Low $\mathrm{N}$} & \multirow[b]{2}{*}{ High N } & \multirow[b]{2}{*}{ Season } & \multicolumn{2}{|c|}{ Harvest of } & \multirow[b]{2}{*}{ Sowing date } & \multirow[b]{2}{*}{$\mathrm{N}_{\min } \dagger$} & \multirow[b]{2}{*}{ Preceding crop } \\
\hline & & & & Seed & Straw & & & \\
\hline & & & & & & & $\mathrm{kg} \mathrm{N} \mathrm{ha}^{-1}$ & \\
\hline Einbeck & $x \neq$ & - & 2010-2011 & $x$ & - & 4 Sept. 2010 & 35 & Winter wheat \\
\hline Göttingen & $x$ & - & 2010-2011 & $x$ & $x$ & 25 Aug. 2010 & 27 & Winter barley \\
\hline Einbeck & $x$ & $x$ & 2011-2012 & - & $x$ & 1 Sept. 2011 & 27 & Winter wheat \\
\hline Göttingen & $x$ & $x$ & 2011-2012 & $x$ & $x$ & 22 Aug. 2011 & 27 & Winter barley \\
\hline Einbeck & $x$ & $x$ & 2012-2013 & $x$ & $x$ & 22 Aug. 2012 & n.a.§ & Winter wheat \\
\hline Göttingen & $x$ & $x$ & 2012-2013 & $x$ & $x$ & 30 Aug. 2012 & 24 & Winter barley \\
\hline
\end{tabular}
calculated as described by Moll et al. (1982).

Table 1. Overview of trials at locations Göttingen and Einbeck at low and high N supply.

† Mineralized $\mathrm{N}$ in the soil.

$\ddagger \mathrm{x}$ indicates trials; - indicates no trials.

$\S$ n.a., not analyzed. 


\section{Statistical Analyses}

Analysis of variance (ANOVA) and broad sense heritabilities $\left(h^{2}\right)$ were calculated using PLABSTAT software (version 3B) (Utz, 2001). To include the effect of different environments (year-location combinations) in the ANOVA, the following model for a split-plot design was used:

$$
Y_{i j k l}=\mu+e_{i}+t_{k}+b_{i j}+\mathrm{et}_{i k}+\varepsilon_{i j k}+g_{k l}+\mathrm{eg}_{i k l}+\varepsilon_{i j k l}
$$

in which $Y_{i j k l}$ was the observation of a genotype $l$ within the growth type $k$ in block $j$ within environment $i$. The overall mean is denoted as $\mu$. The effect of environment is denoted as $e$, growth type as $t$, block as $b$, and genotype as $g$. Interaction effects between growth type and environment were denoted by $e_{i k}$, and interactions between environment and genotype were called eg $_{i k l}$. Whole-plot error was denoted by $\varepsilon_{i j k}$, and the subplot error was denoted by $\varepsilon_{i j k l}$. The factors environment, block, and genotype were considered random.

To test the effects of $\mathrm{N}$ levels, the following model for a split-split-plot design was used:

$$
\begin{aligned}
Y_{i j k l o} & =\mu+e_{i}+n_{o}+b_{i j o}+\mathrm{en}_{i o}+\varepsilon_{i j o}+t_{k}+\mathrm{et}_{i k}+\mathrm{tn}_{k o} \\
& +\operatorname{etn}_{i k o}+\varepsilon_{i j k o}+g_{k l}+\mathrm{eg}_{i l k}+\mathrm{gn}_{k l o}+\mathrm{egn}_{i k l o}+\varepsilon_{i j k l o}
\end{aligned}
$$

in which $Y_{i j k l o}$ is the observation of a genotype $l$ within growth type $k$ at $\mathrm{N}$ level $o$ in block $j$ within environment $i$, and there is the added effect of $\mathrm{N}$ level, $n$. The interaction effects are between environment and $\mathrm{N}$ level en ${ }_{i o}$, environment and growth type et ${ }_{i k}$, environment and genotype $e_{i k l}$, growth type and $\mathrm{N}$ level $\mathrm{tn}_{k o}$, and genotype by $\mathrm{N}$ level $\mathrm{gn}_{k l o}$. Three-fold interactions are for environment by genotype by $\mathrm{N}$ level egn $n_{i k l_{0}}$ and environment by growth type by $\mathrm{N}$ level etn ${ }_{i k o}$. Whole-plot error is denoted by $\varepsilon_{i j o}$, subplot error is denoted by $\varepsilon_{i j k o}$, and sub-subplot error is denoted by $\varepsilon_{i j k l o}$. The factors environment, block, and genotype were considered random.

\section{QTL Analyses}

Linkage map development was performed as described by Miersch et al. (2016), using 100 DH lines of the mapping population 'Alesi-bzh $\times$ H30.' The QTL mapping of testcrosses was performed as established in hybrid crops like maize (Schön et al., 1994) or oilseed rape (Radoev et al., 2008). Quantitative trait loci analyses were performed across environments and for single environments. The QTL confidence interval was defined as LOD-1, following Gadau et al. (2012).

\section{RESULTS}

The impact of $\mathrm{N}$ level was significant for all N-related traits with the exception of NHI, and the effects of environment and $\mathrm{N}$ level $\times$ environment interaction were small relative to the effect of $\mathrm{N}$ level (Table 2). Nitrogen in seeds $\left(\mathrm{kg} \mathrm{N} \mathrm{ha}^{-1}\right)$ and total $\mathrm{N}$ uptake $\left(\mathrm{kg} \mathrm{N} \mathrm{ha}^{-1}\right)$ were affected most by environment if calculated proportionally to the $\mathrm{N}$ level effect (57 and 35\%, respectively). The dominating $\mathrm{N}$-level effect was caused by the large difference in available $\mathrm{N}$ between $\mathrm{N}$ levels (Table 3 ). For seed yield and straw yield, the environment had caused a higher proportion of the total variation than did the $\mathrm{N}$ level (Miersch et al., 2016). Nitrogen harvest index, $\mathrm{N}$ utilization efficiency, and $\mathrm{N}$ use efficiency had the highest heritabilities at low and high $\mathrm{N}$ supply within N-related parameters (Table 2).

\section{Effect of Growth Type on Nitrogen-Related Parameters}

The effect of growth type was significant at low $\mathrm{N}$ supply on $\mathrm{N}$ in straw, NHI, and $\mathrm{N}$ efficiency parameters (Table 2), whereas at high $\mathrm{N}$ supply, the growth-type effect was only significantly effecting $\mathrm{N}$ in straw and $\mathrm{N}$ utilization efficiency.

Differences between growth types were obvious in the spring, when semi-dwarf hybrids were smaller (Miersch et al., 2016) at both $\mathrm{N}$ levels. At maturity, the $\mathrm{N}$ use efficiency and the $\mathrm{N}$ uptake efficiency of semi-dwarf hybrids were significantly higher than those of normaltype hybrids at low $\mathrm{N}$ supply, but there were no respective effects under high $\mathrm{N}$ fertilization (Table 4). The differences in $\mathrm{N}$ uptake efficiency between growth types relate to variation in total $\mathrm{N}$ uptake. While mean values in total $\mathrm{N}$ uptake barely differed under high $\mathrm{N}$ supply, semi-dwarf hybrids had a nonsignificantly higher mean total $\mathrm{N}$ uptake $\left(\mathrm{N} \mathrm{kg} \mathrm{ha}^{-1}\right.$ ) under zero $\mathrm{N}$ fertilization (Table 4).

The $\mathrm{N}$ utilization efficiency was significantly higher at both $\mathrm{N}$ levels for semi-dwarf hybrids (Table 4). The utilization efficiency is calculated by dividing seed yield by total $\mathrm{N}$ uptake. Whereas there was no difference between growth types for total $\mathrm{N}$ uptake under high $\mathrm{N}$ fertilization (Table 4), semi-dwarf hybrids had a higher seed yield compared with normal types (3.31 and $3.21 \mathrm{Mg} \mathrm{ha}^{-1}$, respectively; Miersch et al., 2016), which caused the differences in $\mathrm{N}$ utilization.

Genotypes within the growth type groups varied significantly for most traits at low and at high $\mathrm{N}$ fertilization (Table 2), indicating genetic variation for $\mathrm{N}$-efficiencyrelevant traits. The analysis of the genetic variation of $\mathrm{N}$ use efficiency, according to Moll et al. (1982), showed that the variation contribution from $\mathrm{N}$ uptake efficiency was larger than from $\mathrm{N}$ utilization efficiency (Table 3). This trend was stronger at zero $\mathrm{N}$ than at high $\mathrm{N}$ fertilization. The comparison of the growth types revealed that $\mathrm{N}$ uptake variation is of higher relative importance in semidwarf genotypes than in normal types. This tendency is more pronounced for low $\mathrm{N}$ than for high $\mathrm{N}$ supply.

It can be assumed that the positive effects of the semidwarf growth type on $\mathrm{N}$ use, $\mathrm{N}$ utilization, and $\mathrm{N}$ uptake efficiencies are higher at low than at high $\mathrm{N}$ supply (Tables 3-4). Correspondingly, the semi-dwarf hybrids showed the highest genetic variation for $\mathrm{N}$ uptake efficiency at zero $\mathrm{N}$ fertilization. 
Table 2. Components of variance and respective $F$ tests from the analysis of variance for $\mathrm{N}$-related traits analyzed across $\mathrm{N}$ levels and within trials with low and high N supply, respectively. There were 108 hybrids (54 semi-dwarf and 54 normal-type) grown in three environments (Göttingen 2011 to 2012 and 2012 to 2013, and Einbeck 2012 to 2013). Negative estimates for variance components are given by " 0. ." The complete ANOVA across $N$ levels is presented in Supplemental Table 2.

\begin{tabular}{|c|c|c|c|c|c|c|c|c|c|c|c|}
\hline \multirow[b]{2}{*}{ Source } & \multirow[b]{2}{*}{ Dft } & \multicolumn{10}{|c|}{ Components of variance } \\
\hline & & $\begin{array}{l}\mathrm{N} \text { content } \\
\text { straw }\end{array}$ & $\mathrm{N}$ in straw & $\begin{array}{l}\mathrm{N} \text { content } \\
\text { seeds }\end{array}$ & $\begin{array}{l}\mathrm{N} \text { in } \\
\text { seeds }\end{array}$ & $\begin{array}{c}\text { Seed } \\
\text { protein } \\
\text { content }\end{array}$ & $\mathrm{NHI}$ & $\begin{array}{l}\text { Total N } \\
\text { uptake }\end{array}$ & $\begin{array}{l}\mathrm{N} \text { uptake } \\
\text { efficiency }\end{array}$ & $\begin{array}{c}\mathrm{N} \text { utilization } \\
\text { efficiency }\end{array}$ & $\begin{array}{c}\mathrm{N} \text { use } \\
\text { efficiency }\end{array}$ \\
\hline & & $\%$ & $\mathrm{~kg} \mathrm{~N} \mathrm{ha}^{-1}$ & $\%$ & $\mathrm{~kg} \mathrm{~N} \mathrm{ha}^{-1}$ & $\%$ & & $\mathrm{~kg} \mathrm{~N} \mathrm{ha}^{-1}$ & & & \\
\hline & \multicolumn{11}{|c|}{ Low N supply } \\
\hline Environment (E) & 2 & 0.0002 & $33.1^{\star \star}$ & $0.0148^{\star *}$ & $732.3^{\star \star}$ & $0.58^{\star *}$ & $0.0020^{\star \star}$ & $980.4^{\star \star}$ & 0.0003 & $6.59^{\star}$ & $5.28^{*}$ \\
\hline Growth type $(T)$ & 1 & 0.0000 & $3.4^{*}$ & 0.0007 & 6.3 & 0.03 & $0.0008^{\star}$ & 0 & $0.0019^{\star \star}$ & $1.76^{\star}$ & $4.87^{\star}$ \\
\hline Genotype (G):T & 106 & 0.0002 & $0.9+$ & $0.0014^{\star \star}$ & $2.5+$ & $0.06^{* *}$ & $0.0002^{\star \star}$ & 0.4 & 0.0001 & $0.45^{\star \star}$ & $0.66^{\star \star}$ \\
\hline $\mathrm{T} \times \mathrm{E}$ & 2 & $0.0002^{*}$ & $0.8^{* \star}$ & $0.0012+$ & $5.9^{\star \star}$ & $0.05+$ & $0.0002^{*}$ & $11.6^{\star \star}$ & 0.0001 & $0.24^{\star *}$ & $0.39^{\star \star}$ \\
\hline$(G \times E): T$ & 212 & 0.0001 & $3.0^{* *}$ & $0.0017^{*}$ & $10.4^{\star \star}$ & $0.07^{\star}$ & $0.0003^{\star \star}$ & $18.0^{\star *}$ & 0.0045 & 1.82 & 2.67 \\
\hline$h^{2}$ & & 0.10 & 0.22 & 0.35 & 0.20 & 0.35 & 0.41 & 0.02 & 0.07 & 0.42 & 0.43 \\
\hline \multicolumn{12}{|c|}{ High N supply } \\
\hline E & 2 & $0.0022+$ & $28.0+$ & 0.0000 & $335.9^{\star \star}$ & 0.00 & $0.0019^{\star}$ & $355.2^{\star \star}$ & 0.0014 & $1.79^{\star}$ & $1.77+$ \\
\hline $\mathrm{T}$ & 1 & $0.0041^{\star}$ & $3.8^{\star \star}$ & 0 & 0 & 0 & 0.0001 & 0 & 0 & $0.11+$ & 0.04 \\
\hline G:T & 106 & 0.0004 & $8.6^{\star *}$ & $0.0007^{*}$ & 4.8 & $0.03^{*}$ & $0.0003^{* *}$ & $8.7+$ & 0.0001 & $0.42^{\star *}$ & $0.10^{*}$ \\
\hline $\mathrm{T} \times \mathrm{E}$ & 2 & $0.0004+$ & 0 & $0.0011^{\star \star}$ & $36.3^{\star}$ & $0.04^{\star \star}$ & $0.0002^{*}$ & $33.0^{*}$ & $0.0126^{\star \star}$ & 0.03 & $0.28^{\star \star}$ \\
\hline$(G \times E): T$ & 212 & $0.0037^{\star \star}$ & $12.6^{\star \star}$ & $0.0011+$ & $24.0^{\star \star}$ & $0.04+$ & $0.0003^{\star *}$ & $40.1^{\star \star}$ & 0.0020 & 0.14 & 0.76 \\
\hline$h^{2}$ & & 0.12 & 0.48 & 0.24 & 0.18 & 0.23 & 0.53 & 0.20 & 0.17 & 0.48 & 0.28 \\
\hline \multicolumn{12}{|c|}{ Across $N$ levels } \\
\hline E & 2 & $0.0007+$ & $30.7^{\star}$ & $0.0042^{*}$ & $472.7^{\star \star}$ & $0.16^{\star}$ & $0.0018^{*}$ & $603.4^{\star \star}$ & 0.0014 & 2.30 & 2.03 \\
\hline Nitrogen (N) & 1 & $0.0514^{\star *}$ & $153.4^{\star \star}$ & $0.1042^{*}$ & $822.9^{*}$ & $4.07^{\star}$ & 0.0003 & $1702.7^{\star}$ & $0.0291^{\star}$ & $10.79_{+}$ & $51.20^{\star \star}$ \\
\hline $\mathrm{N} \times \mathrm{E}$ & 2 & 0.0009 & 0 & $0.0065^{\star *}$ & $122.7^{* *}$ & $0.25^{\star \star}$ & $0.0003^{\star *}$ & $128.7^{\star \star}$ & 0.0001 & $1.94^{*}$ & $1.68^{\star *}$ \\
\hline $\mathrm{T} \times \mathrm{N}$ & 1 & $0.0018^{\star \star}$ & 0 & 0.0008 & 0 & 0.03 & $0.0001+$ & 0 & 0.0026 & $0.48^{\star \star}$ & $1.76^{\star \star}$ \\
\hline$(G \times N): T$ & 106 & 0.0001 & $1.38+$ & 0 & 0 & 0 & 0.0000 & 0 & 0 & 0.02 & 0.09 \\
\hline
\end{tabular}

* Significant at the 0.05 probability level; ** significant at the 0.01 probability level; + significant at the 0.1 probability level.

† Df, degrees of freedom.

\section{QTL Analyses}

Quantitative trait loci were estimated for each $\mathrm{N}$ level across environments for all parameters. Significant QTL were only detected within the genomic region of the $b z h$ locus (Table 5). For N-related parameters at zero $\mathrm{N}$ fertilization, QTL for $\mathrm{N}$ efficiencies, NHI, and $\mathrm{N}$ in seeds $\left(\mathrm{kg} \mathrm{N} \mathrm{ha}^{-1}\right)$ were significant. Quantitative trait loci for $\mathrm{N}$ content straw (\%), $\mathrm{N}$ in straw $\left(\mathrm{kg} \mathrm{N} \mathrm{ha}^{-1}\right)$, and total $\mathrm{N}$ uptake $\left(\mathrm{kg} \mathrm{N} \mathrm{ha}^{-1}\right)$ were not significant $(>0.1$ probability level, data not shown) on the A06 linkage group in the region of the bzh locus. The QTL allele inherited from 'Alesi- $b z h$ ' was increasing all traits (Table 5) detected at low $\mathrm{N}$ supply. Herein, the QTL related to NHI, $\mathrm{N}$ use efficiency, and $\mathrm{N}$ utilization efficiency explained the highest proportion of phenotypic variation $(64,60$, and $56 \%$, respectively). The number of parameters with significant QTL at high $\mathrm{N}$ fertilization was lower than for zero $\mathrm{N}$ fertilization (Table 5). The QTL for N uptake efficiency was significant for both $\mathrm{N}$ levels but with adversely directed effects: the 'Alesi- $b z h$ ' allele increased the $\mathrm{N}$ uptake efficiency at $\mathrm{N}$ deficiency but decreased it at high $\mathrm{N}$ fertilization. When single environments were analyzed, QTL on linkage groups other than A06 were detected (Supplemental Table 2), but these proved to be unstable and not significant when analyzed across environments. For the 2012 to 2013 season, just one QTL was estimated to be significant (for $\mathrm{N}$ uptake efficiency, high $\mathrm{N}$ supply, location Göttingen; Supplemental Table 2).

\section{DISCUSSION}

\section{Growth-Type Effects} on Nitrogen-Efficiency-Related Parameters

Genetic variation for $\mathrm{N}$ efficiency parameters exists for all vegetative stages (Balint and Rengel, 2011). Nitrogen uptake after flowering is insufficient as the only $\mathrm{N}$ source for the seed development, and $\mathrm{N}$ remobilization and translocation are then the second source for seed protein and seed yield (Masclaux-Daubresse et al., 2010). Oilseed rape is dropping leaves after flowering during the seed filling period, and delayed leaf senescence was controversially discussed as a selection parameter for $\mathrm{N}$ efficiency (Schulte auf'm Erlay et al., 2007; Kessel et al., 2012; KoeslinFindeklee et al., 2014). In our study, dropped leaves were not collected and the $\mathrm{N}$ loss of dropped leaves was not quantified. In a parallel experiment, Dresbøll et al. (2015) analyzed litter loss in three of the 108 hybrids of this study: one semi-dwarf and two normal-type genotypes. 
Table 3. Relative contribution of $\mathrm{N}$ uptake efficiency and $\mathrm{N}$ utilization efficiency to the total genetic variation in $\mathrm{N}$ use efficiency. Fifty-four semi-dwarf and 54 normal-type hybrids were tested at low and high N supply at two locations, Einbeck (Ei) and Göttingen (Go) in the seasons of 2011 to 2012 and 2012 to 2013. Data from references are given for comparison.

\begin{tabular}{|c|c|c|c|c|c|c|c|}
\hline \multirow[b]{2}{*}{ Environment } & \multicolumn{2}{|c|}{ Low N supply } & \multicolumn{2}{|c|}{ High N supply } & \multirow[b]{2}{*}{$\mathrm{N}_{\min } \dagger$ in spring } & \multicolumn{2}{|c|}{$\mathrm{N}_{\mathrm{s}} \ddagger$} \\
\hline & $\mathrm{N}$ uptake & $\mathrm{N}$ utilization & $\mathrm{N}$ uptake & $\mathrm{N}$ utilization & & Low $\mathrm{N}$ & High $\mathbf{N}$ \\
\hline & & & & & $\mathrm{kg} \mathrm{N} \mathrm{ha}^{-1}$ & & \\
\hline \multicolumn{8}{|l|}{ Go2012§ } \\
\hline Semi-dwarf & 0.70 & 0.30 & 0.75 & 0.24 & 27 & 56.9 & 233.9 \\
\hline Normal type & 0.67 & 0.33 & 0.84 & 0.16 & 27 & 57.3 & 234.3 \\
\hline \multicolumn{8}{|l|}{ Ei2013 } \\
\hline Semi-dwarf & 1.01 & -0.01 & 0.53 & 0.46 & n.a. & 106.9 & 283.5 \\
\hline Normal type & 0.76 & 0.24 & 0.24 & 0.76 & n.a. & 121.1 & 298.1 \\
\hline \multicolumn{8}{|l|}{ Go2013 } \\
\hline Semi-dwarf & 0.91 & 0.07 & 0.81 & 0.18 & 24 & 133.6 & 310.6 \\
\hline Normal type & 0.85 & 0.14 & 0.71 & 0.29 & 24 & 135.1 & 312.1 \\
\hline \multicolumn{8}{|l|}{ Mean } \\
\hline Semi-dwarf & 0.87 & 0.12 & 0.70 & 0.30 & & & \\
\hline Normal type & 0.76 & 0.23 & 0.60 & 0.40 & & & \\
\hline \multicolumn{8}{|l|}{ Reference } \\
\hline Nyikako et al. (2014)ף & 0.68 & 0.32 & 0.46 & 0.54 & $17-33$ & & \\
\hline Kessel et al. (2012)\# & 0.58 & 0.42 & 0.35 & 0.65 & $17-28$ & & \\
\hline
\end{tabular}

† Mineralized $\mathrm{N}$ in the soil.

‡ Ns, total N supply; calculated according to Moll et al. (1982), see Material and Methods.

$\S$ Years denote the harvest year.

In Mean value calculated of 4 environments.

\# Mean value calculated of 3 environments.

They found no significant differences between genotypes for total litter loss and for accumulated $\mathrm{N}$ loss. However, only one semi-dwarf genotype was analyzed, not representing the group of 54 hybrids.

At maturity, the total $\mathrm{N}$ uptake was significantly lower at zero $\mathrm{N}$ fertilization than at high $\mathrm{N}$ supply. With $\mathrm{N}$ as a limiting factor, semi-dwarf and normal-type hybrids reacted differently. Semi-dwarf types had a significantly higher NHI as a result of a reduced straw amount, whereas the $\mathrm{N}$ concentration in the straw remained equal for both growth types. For the significantly larger $\mathrm{N}$ efficiency of semi-dwarf genotypes, the sheer amount of straw made the difference. These results are in contrast to earlier findings of Sieling and Kage (2008) and Koeslin-Findeklee et al. (2014), who did not observe significant differences in HI or NHI between dwarf cultivars and normal-type hybrids; however, they found these results in genotypes that are not directly comparable. In the QTL analysis it could be shown that the alleles of 'Alesi-bzh' that increase $\mathrm{N}$ uptake, $\mathrm{N}$ utilization, and $\mathrm{N}$ use efficiencies and reduce the NHI under low $\mathrm{N}$ supply are located within the genomic region of the dwarf bzh locus (Table 5), which confirmed the direct influence of the dwarf trait for an adaptation to low $\mathrm{N}$ availability. When semi-dwarf and normal-type hybrids were sufficiently fertilized with $\mathrm{N}$, the differences in NHI and $\mathrm{N}$ use efficiency diminished to insignificance. The higher $\mathrm{N}$ uptake efficiency at $\mathrm{N}$ deficiency better adapted semi-dwarf genotypes to a low $\mathrm{N}$ supply than normal-type hybrids.

\section{Relative Contribution of Nitrogen Uptake and Nitrogen Utilization}

Nitrogen use efficiency can be subdivided into $\mathrm{N}$ uptake and $\mathrm{N}$ utilization efficiency. Moll et al. (1982) showed that for maize hybrids at low applied $\mathrm{N}$, the $\mathrm{N}$ utilization efficiency contributed more to the variation in $\mathrm{N}$ use efficiency, whereas at high $\mathrm{N}$ supply, the variation in $\mathrm{N}$ use efficiency was almost completely explained by variation in $\mathrm{N}$ uptake efficiency. In oilseed rape, $\mathrm{N}$ uptake efficiency was described as more important under $\mathrm{N}$ deficiency than under high $\mathrm{N}$ supply (Berry et al., 2010; Schulte auf'm Erlay et al., 2011; Kessel et al., 2012; Nyikako et al., 2014). This general trend was confirmed in this study (Table 3). Beyond that, semi-dwarf hybrids had a higher contribution of $\mathrm{N}$ uptake efficiency to the total genetic variation in $\mathrm{N}$ use efficiency, independent from the $\mathrm{N}$ level, compared with normal-type hybrids.

The question remains why semi-dwarf hybrids have higher NHI and N uptake efficiency under N deficiency compared with normal-type hybrids. The bzh dwarf gene is described as a semidominant mutation and as insensitive to gibberellic acid (gai). The group of gai genes functions as transcription factors controlling the perception and the response to gibberellins (Renard et al., 2010). Nitrogen uptake by the root system could be affected, if the $b z h$ 
Table 4. Mean values of $\mathrm{N}$-efficiency-related parameters of 54 semi-dwarf and 54 normal-type hybrids, tested at low and high N supply in two locations Einbeck (Ei) and Göttingen (Go) in the seasons of 2010 to 2011, 2011 to 2012, and 2012 to 2013.

\section{Environment†}

Trait

Ei2011

Go2011

Ei2012

Go2012

Ei2013

Go2013

Mean

$\mathrm{N}$ content straw (\%)

Semi-dwarf

Normal type

$\mathrm{N}$ in straw $\left(\mathrm{kg} \mathrm{N} \mathrm{ha}^{-1}\right)$

Semi-dwarf

Normal type

$\mathrm{N}$ content seeds (\%)

Semi-dwarf

Normal type

$\mathrm{N}$ in seeds $\left(\mathrm{kg} \mathrm{N} \mathrm{ha}^{-1}\right)$

Semi-dwarf

Normal type

Seed protein content (\%)

Semi-dwarf

Normal type

$\mathrm{N}$ harvest index

Semi-dwarf

Normal type

Total $\mathrm{N}$ uptake $\left(\mathrm{kg} \mathrm{N} \mathrm{ha}^{-1}\right)$

Semi-dwarf

Normal type

$\mathrm{N}$ uptake efficiency

Semi-dwarf

Normal type

$N$ utilization efficiency

Semi-dwarf

Normal type

$\mathrm{N}$ use efficiency

Semi-dwarf

Normal type

$\begin{array}{cc}- & 0.53^{\star *} \\ - & 0.50 \\ - & 18.7^{\star} \\ - & 20.5 \\ 2.72 & 3.07 \\ 2.70 & 3.09 \\ 48.8 & 52.0^{\star *} \\ 46.0 & 39.8 \\ 17.0 & 19.2 \\ 16.9 & 19.3 \\ - & 0.74^{* *} \\ - & 0.66 \\ - & 70.9^{* *} \\ - & 60.6 \\ - & 0.76^{*} \\ - & 0.65 \\ - & 24.1^{* *} \\ - & 21.3 \\ - & 18.3^{* *} \\ - & 13.7 \\ - & \end{array}$

$\mathrm{N}$ content straw (\%)

Semi-dwarf

Normal type

$\mathrm{N}$ in straw $\left(\mathrm{kg} \mathrm{N} \mathrm{ha}^{-1}\right)$

Semi-dwarf

Normal type

$\mathrm{N}$ content seeds (\%)

Semi-dwarf

Normal type

$\mathrm{N}$ in seeds ( $\mathrm{kg} \mathrm{N} \mathrm{ha}^{-1}$ )

Semi-dwarf

Normal type

Seed protein content (\%)

Semi-dwarf

Normal type

$\mathrm{N}$ harvest index

Semi-dwarf

Normal type

Total $\mathrm{N}$ uptake $\left(\mathrm{kg} \mathrm{N} \mathrm{ha}^{-1}\right)$

Semi-dwarf

Normal type

$\mathrm{N}$ uptake efficiency

Semi-dwarf

Normal type

$\mathrm{N}$ utilization efficiency

Semi-dwarf

Normal type

N use efficiency

Semi-dwarf

Normal type

$\begin{array}{ll}- & \\ - & \\ - \\ - \\ - \\ - \\ - \\ - \\ - \\ - \\ - \\ - \\ - \\ - \\ - \\ - \\ - \\ - \\ -\end{array}$

0.60

Low N supply

0.50

0.60

0.50

0.51

$0.55^{\star}$

0.53

0.54

$10.6+$

$9.8^{\star *}$

0.53

0.52

0.53

11.4

$20.1^{\text {** }}$

$17.1^{\text {*夫 }}$

$15.2^{*}$

11.7

24.4

19.1

17.4

3.20

$2.95^{\star \star}$

2.87

$2.71^{\text {** }}$

2.92

3.22

3.04

2.86

2.79

2.95

$37.7^{*}$

64.3

$92.0^{\text {** }}$

$59.0+$

- $\quad 0.56^{\star \star}$

0.50

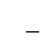

31.7

64.4

85.5

53.5

$18.5^{\star \star}$

17.9

$17.0^{\text {** }}$

17.4

18.3

20.2

19.0

$0.79^{*}$

0.73

$0.76^{\text {** }}$

$0.84^{\text {** }}$

0.82

18.4

$47.4^{\star}$

0.73

$109.1^{\text {** }}$

106.9

88.8

$0.82^{\star \star}$

0.78

0.73

0.75

$26.7^{\text {** }}$

$31.2^{\star \star}$

29.3

$25.5^{\star \star}$

22.7

$0.78^{*}$

0.74

77.9

74.9

$0.80^{\star *}$

0.73

$26.9^{*}$
24.2

$21.1^{\text {**}}$

18.6

18.2

High N supply

$0.85^{\star *}$

0.78

$0.88^{\text {** }}$

$0.95^{\star \star}$

$0.81^{* *}$

$\begin{array}{ll}- & 16.8 \\ - & 16.5\end{array}$

$27.4^{\star \star}$

0.75

0.87

0.72

30.7

$39.2^{\star}$

$32.9^{*}$

$29.7+$

- $3.24^{* *}$

$3.39+$

41.4

35.8

31.1

3.12

3.32

3.32

3.32

3.31

3.31

3.34

2.27

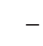

$100.3^{\star \star}$

$91.5^{\star \star}$

124.7

126.0

105.5

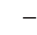

87.3

95.3

20.8

20.8

20.7

$21.2+$

20.8

19.5

\section{$0.79^{\star *}$}

0.74

0.70

0.70

$0.79^{*}$

0.78

0.76

$$
-
$$

$127.7^{\star *}$

118.0

$130.7^{\text {** }}$

136.7

$157.6+$

161.8

138.7

$0.55^{\star *}$

0.46

0.46

$0.51^{* *}$

0.76

0.51

0.50

21.1

23.9+

23.4

$22.6+$

22.420 .9

9.7

$12.7^{\star \star}$

11.3

9.6

9.6

12.1

12.1

11.5 11.0

* Significant at the 0.05 probability level; ** significant at the 0.01 probability level; + significant at the 0.1 probability level.

† Years refer to the harvest year. 
Table 5. The bzh locus and quantitative trait loci (QTL) for N-related traits estimated across environments. One hundred hybrids derived from doubled-haploid population 'Alesi $\times \mathrm{H} 30$ ' crosses with a male-sterile tester were grown at low and high $\mathrm{N}$ supply at locations Einbeck and Göttingen in the 2010 to 2011, 2011 to 2012, and 2012 to 2013 seasons.

\begin{tabular}{|c|c|c|c|c|c|c|}
\hline QTL name & Linkage group & $\begin{array}{c}\text { Confidence } \\
\text { interval }\end{array}$ & Position & Maximum LOD† & Effect‡ & $\mathrm{R}^{2} \S$ \\
\hline & & & $\mathrm{cM}$ & & & \\
\hline \multirow[t]{2}{*}{ bzh-locus } & A06 & & 3.0 & & & \\
\hline & \multicolumn{5}{|c|}{ Low N supply } & \\
\hline \multicolumn{7}{|l|}{$\mathrm{N}$ in seeds, $\mathrm{kg} \mathrm{N} \mathrm{ha}^{-1}$ ? } \\
\hline NkgSeed-NO-A06 & A06 & $0.8-9.8$ & 3.0 & $13.2(0.1)$ & -2.68 & 0.45 \\
\hline \multicolumn{7}{|l|}{$N$ harvest index\# } \\
\hline NHI-NO-A06 & A06 & $1.0-2.6$ & 2.1 & $21.9(0.05)$ & -0.03 & 0.64 \\
\hline \multicolumn{7}{|l|}{ N uptake efficiency\# } \\
\hline NupEff-NO-A06 & A06 & $1.2-7.9$ & 3.1 & $13.0(0.1)$ & -0.04 & 0.44 \\
\hline \multicolumn{7}{|l|}{ N utilization efficiency\# } \\
\hline NutEff-NO-A06 & A06 & $0.9-8.5$ & 3.0 & $18.2(0.05)$ & -1.10 & 0.56 \\
\hline \multicolumn{7}{|l|}{$\mathrm{N}$ use efficiency\# } \\
\hline NUE-N0-A06 & A06 & $1.3-8.5$ & 3.1 & $20.2(0.1)$ & -1.72 & 0.60 \\
\hline \multicolumn{7}{|c|}{ High N supply } \\
\hline \multicolumn{7}{|l|}{ N content straw, \%\# } \\
\hline N\% straw-N1-A06 & A06 & $1.2-10.6$ & 3.1 & $12.5(0.1)$ & -0.04 & 0.44 \\
\hline \multicolumn{7}{|l|}{ N uptake efficiency $\dagger \dagger$} \\
\hline NupEff-N1-A06 & A06 & $1.3-9.0$ & 3.8 & $23.3(0.05)$ & 0.04 & 0.65 \\
\hline
\end{tabular}

† Significant at the 0.1 or 0.05 probability level.

‡ Effect of substituting the allele of parent 'Alesi-bzh' by the allele of parent ' $\mathrm{H} 30$.'

$\S$ The proportion of phenotypic variance explained by the QTL.

I Phenotype data from five environments.

\# Phenotype data from four environments.

†† Phenotype data from three environments.

locus would not only change the shoot but also the root architecture. Dresbøll et al. (2015) studied the root characteristics of three of the 108 hybrids analyzed in this study: one semi-dwarf and two normal types. Root growth was analyzed using minirhizotrons of $2.3-\mathrm{m}$ soil depth, detecting no significant genotype differences in root depth and intensity. Dresbøll et al. (2015) concluded that the $b z h$ locus did not affect root characteristics, but only one semi-dwarf hybrid was analyzed. If we assume there is no difference in the root system between semi-dwarf and normal-type hybrids, how could we then explain the differences in $\mathrm{N}$ uptake efficiency between semi-dwarf and normal types at $\mathrm{N}$ deficiency?

For three environments, some $\mathrm{N}$-related parameters can be compared (Table 6):

If $\mathrm{N}$ is not limited, then total $\mathrm{N}$ uptake was identical for semi-dwarf and normal-type hybrids and $\mathrm{N}$ was distributed on straw and seeds in semi-dwarf and normal types in the same ratio (high $\mathrm{N}$ supply, NHI is identical; Table 6). When $\mathrm{N}$ is not limited, the $\mathrm{N}$ content in the straw was higher in semi-dwarfs compared with normal types, since the same amount of $\mathrm{N}$ was taken up by semidwarf plants, despite their reduced biomass.

If $\mathrm{N}$ is limited, then the total $\mathrm{N}$ uptake was identical for semi-dwarf and normal type, but the $\mathrm{N}$ distribution ratio between seeds and straw was changed (low $\mathrm{N}$ supply, NHI semi-dwarf $>$ NHI normal type). It seems that $\mathrm{N}$ was translocated more efficiently into the seeds.

\section{Phenotyping Nitrogen Use Efficiency Parameters}

How to choose the level of $\mathrm{N}$ in $\mathrm{N}$ stress phenotyping? Two major strategies are possible: Either a moderate $\mathrm{N}$ stress is applied that is representative for the situation of future crop production systems under the "nitrates directive," or the stress is maximized by zero $\mathrm{N}$ fertilization so that plants show severe stress symptoms, with stress reactions able to be scored easily. Bouchet et al. (2014) tested oilseed rapeseed populations under high and low $\mathrm{N}$ supply, where $\mathrm{N}$ levels differed by 80 to $90 \mathrm{~kg} \mathrm{~N} \mathrm{ha}^{-1}$. They detected only small genotype $\times \mathrm{N}$ interactions and mainly found QTL that were constitutive under low and high $\mathrm{N}$ fertilization for yield parameters. In the current study, no $\mathrm{N}$ was added in the lower $\mathrm{N}$ level. This resulted in a high $\mathrm{N}$ stress at the zero $\mathrm{N}$ supply level in the relatively dry 2011 to 2012 season, and in a less intensive $\mathrm{N}$ stress in the 2012 to 2013 season $\left(N_{s}\right.$; Table 5), where more rain fall in early summer and $\mathrm{N}$ mineralization was assumed to be higher. The $\mathrm{N}$ fertilization levels within all trials differed by $177 \mathrm{~kg} \mathrm{~N} \mathrm{ha}^{-1}$, but the $\mathrm{N}$ stress level in 2012 to 2013 
was so low that only one trial-specific QTL was detected (Supplemental Table 2) even though significant differences in traits were observed. This might also be due to the fact that the number of lines tested within this QTL study was small with respect to the QTL detection accuracy, which made the estimation of QTL for less dominant traits difficult (Miersch et al., 2016). The reaction of the genotype to severe stress is, however, different from the reaction to moderate stress (Han et al., 2015), and selecting for a reaction to moderate stress is closer to reality in plant production. Including more $\mathrm{N}$ levels in the field trials would solve this problem, but this would increase the field testing costs. We therefore recommend to include a zero $\mathrm{N}$ fertilizer level in all experiments, because on sites with fertile soils typical for rapeseed production in Central Europe, a reduction of fertilizer input by less than $100 \mathrm{~kg} \mathrm{~N} \mathrm{ha}^{-1}$ will, in many seasons, hardly result in any effect.

In this study, significant genetic variation within growth types was observed for traits with higher heritability, such as NHI, N utilization efficiency, and $\mathrm{N}$ use efficiency. Correlations between low and high $\mathrm{N}$ levels were not high for NHI and $\mathrm{N}$ use efficiency $(r=0.63$ and 0.64, respectively; Supplemental Table 3) and were even lower for $\mathrm{N}$ utilization efficiency and $\mathrm{N}$ uptake efficiency ( $r=0.53$ and -0.29 , respectively). For the selection of genotypes adapted to $\mathrm{N}$ deficiency, trials should be performed at low and high $\mathrm{N}$ supply.

\section{CONCLUSIONS}

The advantages of a higher HI are obvious in wheat and rice (Oryza sativa L.), where dwarf genes were introduced during the course of the Green Revolution (Hedden, 2003), leading to today's lodging-resistant and high-yielding cultivars. If straw is not harvested, as is done in oilseed rape, it

Table 6. Mean values of seed yield, straw yield, harvest index $(\mathrm{HI}), \mathrm{N}$ harvest index (NHI), and total N uptake. Fifty-four semi-dwarf and 54 normal-type hybrids were tested at low and high N supply in three environments: Einbeck (2012 to 2013) and Göttingen (2011 to 2012 and 2012 to 2013).

\begin{tabular}{lccc}
\hline Trait & \multicolumn{2}{c}{ Semi-dwarf } & Normal type \\
\hline \multicolumn{4}{c}{ Low N supply } \\
Seed yield $\left(\mathrm{Mg} \mathrm{ha}^{-1}\right) \dagger$ & 2.30 & $>\ddagger$ & 2.12 \\
Straw yield $\left(\mathrm{Mg} \mathrm{ha}^{-1}\right) \dagger$ & 2.93 & $<$ & 3.52 \\
$\mathrm{HI \dagger}$ & 43.1 & $>$ & 36.8 \\
$\mathrm{NHI}$ & 0.80 & $>$ & 0.76 \\
Total N uptake $\left(\mathrm{kg} \mathrm{N} \mathrm{ha}^{-1}\right)$ & 80.3 & $=$ & 78.9 \\
& \multicolumn{4}{c}{ High N supply } \\
Seed yield $\left(\mathrm{Mg} \mathrm{ha}^{-1}\right) \dagger$ & 3.16 & $=$ & 3.09 \\
Straw yield $\left(\mathrm{Mg} \mathrm{ha}^{-1}\right) \dagger$ & 3.71 & $<$ & 4.51 \\
HI† & 46.3 & $>$ & 40.9 \\
NHI & 0.76 & $=$ & 0.74 \\
Total N uptake $\left(\mathrm{kg} \mathrm{N} \mathrm{ha}^{-1}\right)$ & 138.7 & $=$ & 138.8 \\
\hline
\end{tabular}

† Refer to Miersch et al. (2016).

$\ddagger$ Symbols $<$ and $>$ indicate the direction of significant differences between growth types; = indicates no significant difference between growth types. is a dead sink for fertilized nutrients and assimilates that are left in the field, and might lead to $\mathrm{N}$ leaching after harvest.

In winter oilseed rape, semi-dwarf hybrids were released to the French market in 1999, but despite a higher lodging resistance, increased winter hardiness, better harvest ability (Pinochet and Renard, 2012), and higher drought tolerance compared with normal-type hybrids, they so far have not gained a market share in Western Europe. In the current discussion on how to breed N-efficient winter oilseed rape cultivars, major tasks include how to reduce $\mathrm{N}$ fertilization without losing yield, and how to avoid $\mathrm{N}$ leaching from plant debris after harvest? Genotypes with a reduced height, such as the semi-dwarf hybrids in this study, might give a direction. Miersch et al. (2016) observed that $b z h$ semi-dwarf hybrids had a higher seed yield compared with normal-type hybrids when $\mathrm{N}$ was reduced and showed no yield penalty at optimal $\mathrm{N}$ fertilization. In the current study, $b z h$ semi-dwarf hybrids proved to leave less $\mathrm{N}$ in straw in the field after harvest and had a higher $\mathrm{N}$ use efficiency and NHI. Thus, they were better adapted to low $\mathrm{N}$ fertilization compared with normal-type hybrids. A higher input into semi-dwarf breeding programs should therefore result in yield-stable, semi-dwarf hybrids at high and at low $\mathrm{N}$ supply.

\section{Supplemental Material Available}

Supplemental material for this article is available online.

\section{Acknowledgments}

The authors gratefully acknowledge funding from the European Community financial participation under the Seventh Framework Programme for Research, Technological Development and Demonstration Activities, for the Integrated Project NUE-CROPS FP7-CP-IP 222645. The views expressed in this publication are the sole responsibility of the author and do not necessarily reflect the views of the European Commission. Neither the European Commission nor any person acting on behalf of the Commission is responsible for the use which might be made of the information contained herein.

\section{References}

Balint, T., and Z. Rengel. 2011. Nitrogen and sulfur uptake and remobilisation in canola genotypes with varied $\mathrm{N}$ - and S-use efficiency differ at vegetative and maturity stages. Aust. J. Agric. Res. 62:299-313.

Berry, P.M., J. Spink, M.J. Foulkes, and P.J. White. 2010. The physiological basis of genotypic differences in nitrogen use efficiency in oilseed rape (Brassica napus L.). Field Crops Res. 119:365-373. doi:10.1016/j. fcr.2010.08.004

Bouchet, A.-S., N. Nesi, C. Bissuel, M. Bregeon, A. Lariepe, H. Navier, N. Ribière, M. Orsel, B. Grezes-Besset, M. Renard, and A. Laperche. 2014. Genetic control of yield and yield components in winter oilseed rape (Brassica napus L.) grown under nitrogen limitation. Euphytica 199:183-205. doi:10.1007/s10681-0141130-4 
Council of the European Communities. 1991. Council Directive of 12th December 1991 on the protection of waters against pollution caused by nitrates from agricultural sources (91/676/EEC). Official Journal of the European Community L375:1-8.

Deutsche Düngeverordnung. 2006. Regulation on the use of fertilizers, soil improvers, growing media and plant additives according to the principles of good agricultural practice in manuring. (In German.) Bundesministerium der Justiz and für Verbraucherschutz. http:// www.gesetze-im-internet.de/d_v/BJNR002000006.html (accessed 13 Nov. 2015)

Dresbøll, D.B., I.S. Rasmussen, and K. Thorup-Kristensen. 2015. The significance of litter loss and root growth on nitrogen efficiency in normal and semi-dwarf winter oilseed rape genotypes. Field Crops Res. 186:166-178. doi:10.1016/j.fcr.2015.12.003

European Parliament and the Council of the European Union. 2009. Directive 2009/28/EC of the European parliament and of the council of 23 April 2009 on the promotion of the use of energy from renewable sources and amending and subsequently repealing Directives 2001/77/EC and 2003/30/EC. Official Journal of the European Community L140:39-85.

Foisset, N., R. Delourme, P. Barret, and M. Renard. 1995. Molecular tagging of the dwarf BREIZH (Bzh) gene in Brassica napus. Theor. Appl. Genet. 91:756-761. doi:10.1007/BF00220955

Foisset, N., R. Delourme, P. Barret, N. Hubert, B.S. Landry, and M. Renard. 1996. Molecular mapping analysis in Brassica napus using isozyme, RAPD and RFLP markers on a doubled haploid progeny. Theor. Appl. Genet. 93:1017-1025. doi:10.1007/BF00230119

Gadau, J., C. Pietsch, and L.W. Beukeboomifkin. 2012. Quantitative trait locus analysis in haplodiploid Hymenoptera. In: S.A. Rifkin, editor, Quantitative trait loci (QTL), methods and protocols. Springer Verlag, Heidelberg, Germany. p. 313-328. doi:10.1007/978-1-61779785-9_16

Girke, A., A. Schierholt, and H.C. Becker. 2011. Extending the rapeseed genepool with resynthesized Brassica napus L. I. Genetic diversity. Genet. Resour. Crop Evol. 59:1441-1447. doi:10.1007/s10722-0119772-8

Good, A.G., A.K. Shrawat, and D.G. Muench. 2004. Can less yield more? Is reducing nutrient input into the environment compatible with maintaining crop production? Trends Plant Sci. 9:597-605. doi:10.1016/j.tplants.2004.10.008

Han, M., M. Okamoto, P. H. Beatty, S. J. Rothstein, and A.G. Good. 2015. The genetics of nitrogen use efficiency in crop plants. Annu. Rev. Genet. 49:269-289. doi:10.1146/annurev-genet-112414-055037

Hedden, P. 2003. The genes of the Green Revolution. Trends Genet. 19:5-9. doi:10.1016/S0168-9525(02)00009-4

Henke, J., K. Sieling, W. Sauermann, and H. Kage. 2009. Analysing soil and canopy factors affecting optimum nitrogen fertilization rates of oilseed rape (Brassica napus). J. Agric. Sci. 147:1-8. doi:10.1017/ S0021859608008162

Kessel, B., A. Schierholt, and H.C. Becker. 2012. Nitrogen use efficiency in a genetically diverse set of winter oilseed rape (Brassica napus L.). Crop Sci. 52:2546-2554. doi:10.2135/cropsci2012.02.0134

Koeslin-Findeklee, F., A. Meyer, A. Girke, K. Beckmann, and W.J. Horst. 2014. The superior nitrogen efficiency of winter oilseed rape (Brassica napus L.) hybrids is not related to delayed nitrogen starvation-induced leaf senescence. Plant Soil 384:347-362. doi:10.1007/ s11104-014-2212-8
Lancashire, P.D., H. Bleiholder, P. Langelüddecke, R. Strauss, T. van den Bloom, E. Weber, and A. Witzen-Berger. 1991. A uniform decimal code for growth stages of crops and weeds. Ann. Appl. Biol. 119:561-601. doi:10.1111/j.1744-7348.1991.tb04895.x

Masclaux-Daubresse, C., F. Daniel-Vedele, J. Dechorgnat, F. Chardon, L. Gaufichon, and A. Suzuki. 2010. Nitrogen uptake, assimilation and remobilization in plants: Challenges for sustainable and productive agriculture. Ann. Bot. (Lond.) 105:1141-1157. doi:10.1093/aob/ mcq028

Miersch, S., A. Gertz, F. Breuer, A. Schierholt, and H.C. Becker. 2016. Influence of the semi-dwarf growth type on seed yield and agronomic parameters at low and high nitrogen fertilization in winter oilseed rape. Crop Sci. doi:10.2135/cropsci2015.09.0554

Moll, R.H., E.J. Kamprath, and W.A. Jackson. 1982. Analysis and interpretation of factors which contribute to efficiency of nitrogen utilization. Agron. J. 74:562-564. doi:10.2134/agronj1982.00021962007 400030037x

Nyikako, J., A. Schierholt, B. Kessel, and H.C. Becker. 2014. Genetic variation in nitrogen uptake and utilization efficiency in a segregating DH population of winter oilseed rape. Euphytica 199:3-11. doi:10.1007/s10681-014-1201-6

Pinochet, X., and M. Renard. 2012. Progrès génétique en colza et perspectives. (In French with English abstract.) Oilseeds and fats, Crops and Lipids 19:147-154. doi:10.1051/ocl.2012.0456

Renard, M., R. Delourme, P. Barret, D. Brunel, N. Froger, and X. Tanguy. 2010. Mutant gene of the GRAS family and plants with reduced development containing said mutant gene. US Patent 7645920 B1. Date issued: 12 January.

Radoev, M., H.C. Becker, and W. Ecke. 2008. Genetic analysis of heterosis for yield and yield components in rapeseed (Brassica napus L.) by quantitative trait locus mapping. Genetics 179:1547-1558. doi:10.1534/genetics.108.089680

Schön, C.C., A.E. Melchinger, J. Boppenmaier, E. Brunklaus-Jung, R.G. Herrmann, and J.F. Seitzer. 1994. RFLP mapping in maize; quantitative trait loci affecting test cross performance of elite European flint lines. Crop Sci. 34:378-389. doi:10.2135/cropsci1994.0011183 X003400020014x

Schulte auf'm Erlay, G., K.-A. Wijaya, A. Ulas, H.C. Becker, F. Wiesler, and W.J. Horst. 2007. Leaf senescence and $\mathrm{N}$ uptake parameters as selection traits for nitrogen efficiency of oilseed rape cultivars. Physiol. Plant. 130:519-531. doi:10.1111/j.1399-3054.2007.00921.x

Schulte auf'm Erlay, G., T. Behrens, A. Ulas, F. Wiesler, and W. J. Horst. 2011. Agronomic traits contributing to nitrogen efficiency of winter oilseed rape. Field Crops Res. 124:114-123. doi:10.1016/j. fcr.2011.06.009

Sieling, K., and H. Kage. 2008. The potential of semi-dwarf oilseed rape genotypes to reduce the risk of $\mathrm{N}$ leaching. J. Agric. Sci. 146:77-84. doi:10.1017/S0021859607007472

Sylvester-Bradley, R., and D.R. Kindred. 2009. Analysing nitrogen responses of cereals to prioritize routes to the improvement of nitrogen use efficiency. J. Exp. Bot. 60:1939-1951. doi:10.1093/jxb/erp116

Utz, H. 2001. Plabstat- ein Computerprogramm zur statistischen Analyse von pflanzenzüchterischen Experimenten. Institut für Pflanzenzüchtung, Saatgutforschung und Populationsgenetik der Universität Hohenheim, Stuttgart, Germany.

VDLUFA. 1991. VDLUFA Methodenhandbuch Band 1. Die Untersuchung von Böden. 4th ed. (In German.) VDLUFA-Verlag, Darmstadt, Germany. 